УДК 81'255.2:82-14-057.87

https://doi.org/10.31548/philolog2020.02.046

\title{
GAUDEAMUS: FROM SOURCE OF ORIGIN TO CULT
}

\author{
I. I. VAKULYK, PhD in Philology, Associate Professor, \\ National University of Life and Environmental Sciences of Ukraine \\ E-mail:vakulyk@ukr.net \\ http://orcid.org/0000-0002-4812-7719
}

\begin{abstract}
The existing versions of the ancient student song are discussed and the original source of the world-famous hymn is identified in this article. The purpose of the presented work is to isolate and explore the existing variants of the ancient student song, to establish their subordination and authorship, to determine the source of the world-famous hymn. The discovering of the mechanism of creation of the medieval song "Gaudeamus» and its modern reading is the scientific novelty in this area. The analysis of the latin text in comparison with the modern interpretation of ancient poetry by scientists of Russia, Germany and Spain was the basis for the study. The maximum objectivity in presenting factual material was found in this work. A method of dialogical interpretation of the text, in particular its cultural and historical aspect, was used in order to study the work.
\end{abstract}

Conclusions. The literary and musical part of the texts of the student hymn from the very first printed versions, which are stored in the archives, are analyzed; literary versions of the song are presented and their authorship is determined; the authors of the musical accompaniment have been identified, based on the existing versions of the hymn. The cult of ancient song and its origin, started by the Germans, that became a bestseller in music and became the world hymn of youth, is proved.

Keywords: modern student anthem, medieval goliard's songs, "Gaudeamus», perception phenomenon, interpretation.

Introduction. «Gaudeamus» is traditionally believed to be the anthem of student youth, that is, a praise song that has received worldwide recognition. It is the first time it has sounded on the occasion of the 800th anniversary of the University of Bologna in 1886, and since then it has been heard annually in the educational institutions of Germany, France, Spain, Russia, Ukraine, student organizations of Austria and Switzerland, and sounds in almost all official academic ceremonies of higher education institutions.

"Gaudeamus» begins every academic year at the Catholic University of Leuven in Belgium and can be heard on the day of exams at US colleges and universities, in the repertoire of Yale University. The hymn's awareness has been embraced by both modern media (think of advertising two years ago on Ukrainian television) and European cinema (Journey to the Center of the Earth (1959)) by J. Verne, when Professor O. Lindenbrook happily returns to his university (2008) [10; 12]. In the Baltic countries, since 1956, folk music festivals that sought to revive national traditions opened with the affirmative words "Gaudeamus igitur». So the cult of the ancient song, started by the Germans, has become a bestseller in music.

Recent researches and publications. One of the factors that preserve a text in a culture that is conditioned by the perception of an ethnic group is its interpretation. Therefore, scientists, exploring the new textual meanings of "Gaudeamus", considered it as an object of logical and grammatical analysis (J. Fuld, J. le Goff), giving preference to sources of origin and metrics (O. Sobolevsky, L. Ginzburg, A. Fedorov, A. Sodomora, M. Golubev, I. Vakulyk).

The purpose of the presented work is to isolate and explore the existing variants of the ancient student song, to establish their subordination and authorship, to determine the source of the world-famous hymn. The 
discovering of the mechanism of creation of the medieval song "Gaudeamus» and its modern reading is the scientific novelty in this area. The analysis of the latin text in comparison with the modern interpretation of ancient poetry by scientists of Russia, Germany and Spain was the basis for the study. The maximum objectivity in presenting factual material was found in this work. A method of dialogical interpretation of the text, in particular its cultural and historical aspect, was used in order to study the work.

Results. When J. Brahms (1833-1897) from the University of Breslau was awarded the honorary title of Doctor in 1881, he wrote on the motifs of various student songs "Overtures of the Academic Festival» (Op. 80) for the orchestra [7], where in the finale had to sound "Gaudeamus igitur» $[15 ; 16]$. There is another version about the origins of «song songs»: Spanish sources suggest that it comes from Finland (1582), but scientists cannot prove it because they did not find its basis [13]. Subsequently, the tune of "Gaudeamus» was used by J. Brahms, H. Berlioz, A.Kos-Anatolsky, E. Humperdnik (opera from the life of a German student), in Russia - by P.Tchaikovsky (in 1874 translated for4-voice male choir. In the same year, under the pseudonym $\mathrm{BL}$ - this is how the music feuilletons were signed - a choral score was issued) [8; 3].

There are two versions for writing music for the student youth anthem [2].

A. Fallerslebenn in his essay, dated 1872, wrote of "Gaudeamus»: "... I have found and kept a manuscript of the sixteenth century. The title of which contains «Hymnus paranymphus» («The Bridegroom's Praise Song» - hereinafter translated I.Vakulyk) on the occasion of the marriage of M. Luther in 1525 with the question «ls it written to the same tune? ". He also points to the number of lines in the song -54 , which are divided into 18 stanzas, and further explains the principle of verifying the work.

The Latin song "Gaudeamus igitur» is extremely related to the fun German «Have Fun, Brethren! ", which is the origin of the table songs written by J. Gunter in 1717 . It was first published in the posthumous collection of Gunter's poems. M. Fedorov also adds the year of publication of "Collected Works» of the author - 1730, Frankfurt, Leipzig. The scientist claims that the poet from Prussian Silesia also belongs to the tune. The same opinion about music authorship is held by Spanish researchers [13].

The oldest version of the student anthem, written in Latin, is in the manuscript collection "Student Songs», which is stored in the Berlin State Library, and previously in the West German Library in Marburg, the former library of the Prussian Cultural Heritage Foundation $[7 ; 13 ; 16]$.

There is a clear reference to the song "Gaudeamus itaque, Burschii dum sumus» in the Latin work "On the Norms of Student Life», or "Comments on Bursaks», published in 1780. German scholars suggest that the author could have been C. Gleiz (17521784). In a study published under the pseudonym of N. Balger in 1798, we read: «When we graduate from university, we leave our rights. We will do what we want, so have fun while we are young. Let's use our rights, privileges and immunities!» [2].

The first printed text of a student song appeared in the literary edition of the German poet C. Kindleben in 1781 [3]. The Student Songs by $H$. Kindleben on page 52 provides a German translation of an ancient Latin song, on page 56 the author notes that he made significant changes to the Latin text. Copies of this document have not been preserved; however, there is a facsimile edition of 1894 , which is stored in the holdings of the library of Harvard University. Here, as noted by Golubeva, there are 10 stanzas of Kindleben's text, which are significantly different from the original version. At the same time (1781) another Kindleben work, Studenten lexicons, was published, which was probably one of the reasons for the dismissal of the Dean of the Faculty.

In 1783, the tune entered the «Academic Singing» of A. Niemann («Akademisches Liederbuch», second edition - 1795), Yel University. In Leipzig, 1788, «Songs for the comfort of companion 
friends» are dated. Here were presented 3 poems for singing with a melody (placed on p.24). Student songs have become so popular at German universities that they continue to be published by the merchant (J. Rüdiger, Trink oder Commerschlieder Halle, 1791; H. Raufseisen's collection, Akademisches Lustw äldlein - Altdorf, 1794; Keild Deutsche Studentenlieder das XVII u. XVIII S., Teibner's collections in Leipzig and Schauenburg in Larry) [9].

It is likely that the student song in the XVIII century was transmitted verbally, what was conditioned by the nature of its performance: from burlesque to giving the song the sound of obscene content. Therefore, Kindleben adapted the text to print and freed it from all disgusting and immoral passages [14]. He wrote: «I need to revise this ancient student song because some of its poetic lines were completely absent, resulting in true poetry being corrupted and having no right to claim academic laws» [2].

For the first time, the Latin text, Fedorov says, is accompanied by music in the opaque version of Dr. Faust by Ignatius Walter, which was performed in Bremen in 1797. Students sing the famous words of an ancient song, which is the embodiment of a free, no-burdensome life in Auerbach's cellar. No print edition of this work found [15]. With minor changes, one could see Gaudeamus in the 19th century. It is a novelty in the Books of the Comershells [9], as well as a song heard in the student taverns.

As noted by J. Ames in Bibliographic Description [10, 186], the characteristic feature of commercial ceremonies was the observance of the corporate hierarchy of participants and requirements for wearing clothes, performing certain rites (eg, the arrangement of tables in the form of letters $U$ and $W$ ) etc. If we consider the etymological source of the term, the Latin Sommercium, in (also in pl) «communication, community, relationships, connection». So we read in T. Livius: commercium linguae; commercium sermonum; in $\mathrm{K}$. Tacitus - commercium loquendi audiendique [4, 210]. As for der Kommers, this term in Central and Eastern Europe (but mostly in German and Baltic student life) was called a student feast that accompanied any university celebration, even the beginning and end of the semester (in honor of those who joined the student corporation, as well as those who have completed the course of study) [9]. She could also be heard in the streets on the eve of the revolutionary 1829. R. Wagner, in his Autobiography, recalls that in 1830 there were groups of students who were arrested for street riots, and their university friends, singing to Gaudeamus, went to release their colleagues.

Since 1848, the view of the song has changed. It became not only an integral part of the canons of German students, but was extremely popular because of its age.

It is known that the Latin manuscript was first discovered in 1267 in the Paris National Library. The words of some of the lines are almost identical to modern ones, though the expression "Gaudeamus igitur» does not appear. The manuscript also has music, but it is not at all like the tune we know. The manuscript begins with the words «Scribere proposui» [7].

The first line of «Let's Have Fun!» was taken by an unknown author from the Easter Service [7]. Regarding the real name of the song «De brevitate vitae» («On the transience of life») [8], it comes from the philosophical treatise of the Roman writer and statesman L. Seneca [4, 75; 1 , 344], author of tragedies on mythological subjects («Medea», «Phaedra», «Oedipus») and ethical works («On friendship», «On gratitude», «On predetermination»). In the VI. Seneca's apocryphal correspondence with the apostle Paul was compiled, for which St. Jerome made it to the list of saints. "Life only seems too short for people who do not spend their lives in intervals but spend on indecent acts, wrote the Roman» [17; 1, p. 345].

The saying became firmly in the language and became the custom of «All its time, and everything has its time». This phrase comes from the following text: «For 
all your time and hour your every business in the sky: time to be born and time to die, time to plant and time to tear planted, time to kill and time to heal, time to destroy and time to build, time to cry and time to growl, to cry and time to dance ... Forcing these opposite concepts, the author reinforces the idea: life is fleeting, it is necessary to live today, now, because tomorrow is the time to love and perhaps it is time to hate - one will lose the most expensive ...» $[5,121]$.

Recall that the beginning of university education was associated with intensive study of ancient literature, so the abovementioned work of L. Seneca was wellknown and its references are not accidental.

Repeatedly, Gaudeamus has been translated into various languages of the world: English («While we're young, let us rejoice ...»), German («Lebt, so lang die Jugend schaumt ...»), Spanish («Alegremonos pues, mientras seamos jovenes»), Belarussian («To experience the joy of life for the Young One»), Finnish («Riemuitkaamme, viela on suonissamme tulta! ..»), Esperanto («Goju, goju, ni colleoj, dum ni junaj estas! ...) [3]. In Russia, Gaudeamus was translated by M. Bugaev, Professor of Mathematics at Moscow University, A.Bely's father [7, 12].

"Gaudeamus» was so popular with the student body of the late 19th - early 20th centuries that several musical variants to this text have been preserved. The name of the play L. Andreev's "Days of Our Life»

\section{Список використаних джерел}

1. Антична література / Миронова В. (кер. авт. кол.), Михайлова О., Мегела І. та ін. К.: Либідь, 2005. 488 с.

2. Вакулик I. Джерела походження культу старовинної студентської пісні. Studia Linguistica, 2011. Вип. 5. Ч. 2. С. 6470.

3. Голубева М. Санкт-Петербургский университет, 2008. №11 $\quad$ (3778), 29 августа.

4. Дворецкий И. Латинско-русский словарь. М.: Русский язык, 1996. 1096 с.

5. Коваль А. Спочатку було Слово:
(1908), which refers to the everyday life of Russian students, is also inspired by the medieval song. Speaking of contractual translation, the most authoritative work is the study of S. Sobolevsky, a classical philologist, professor, author of numerous works in ancient Greek and Latin. In the Ukrainian literature, the most preferred are translations by $A$. Sodomora, a student of $G$. Kochur.

Conclusion and Prospects. «lt is not the achievement of technology, but the weight of the Word in society determines the extent of its civilization», A. Sodomora said in an interview with The Day newspaper in 2000. «Speaking of a translator, he must be receptive to those» drops of eternity» (V. Hugo), who encoded in the artistic text of the time. He coded that we, having partaken of the eternal and the good, would pass on this drop to future generations. In this friendliness, the highest content of literature, of art in general. Perhaps those who claim that the value of a work of art is not only in what the author wanted to say about his age, but also in what this work can give to the modern reader, are right. "For the sake of the future, I work, communicate with them», Seneca wrote more than two thousand years ago.

Thus, having considered and researched all known versions of the origin of the student hymn "Gaudeamus», we established their subordination and authorship, made attempts to determine the source of the world-famous hymn.

Крилаті вислови біблійного походження в українській мові. К.: Либідь, 2001. 312 с.

6. Содомора А. Не достижения техники, а вес Слова в обществе определяет меру его цивилизованности. День, 2000. № 226, 8 декабря

7. Федоров, Н. «Возвеселимся же!» Независимая газета, 2001. № 12 (2322). 25 января.

8. Флоренский П. Христианство и культура. Символ, № XXI, С. 69-83.

9. Энциклопедический словарь / сост. Ф. А. Брокгауз, И. А. Ефрон. URL: http://www.vehi.net/brokgauz/ 
10. Allgemeines Deutsches Commersbuch. Erstausgabe 1858. URL: http://www.academiccorporations.org/world/ita ly/history

11. Ames J. S. Biographical Memoir. Vol. XXIII. National Academy of Sciences of the United States of America. Presented to the Academy at the annual meeting, 1944. p. 186. URL:http://www.nap.edu/html/biomems/jame. pdf.

12. Gaudeamus igitur. Lat uns frhlich sein. Historische Studentenlieder, zusammengestellt, bearbeitet und kommentiert von Gnter Steiger und Hans-Joachim Ludwig, 1. Auflage Leipzig (DDR) 1986, 3. Auflage, Leipzig (DDR) 1989.

URL:http://www.akadpress.de/studentika/buec her/steigergaudeamusigitur.html

13. Gaudeamus igitur, el himno universitario / 500 aos en la historia de Sevilla.URL:http://personal.us.es/alporu/hist oria/gaudeamus.html

14. Kindleben C., Augustin C. Deutscher Abend in Halle, Verlag Fliegenkopf, Halle, Reprint der Ausgabe von 1894, 2000. URL: http://www.arbeitsgemeinschaft.net/article/

Gaudeamus_igitur

15. Probst-Effah G. «Gaudeamus igitur» - ein Beitrag zum deutschen Studentenlied I Gisela Probst-Effah. URL: http://deutsch.astrasong.ru/c/de/art/466

16. Schauenburg M. Allgemeines Deutsches Kommersbuch / Herausgeber: Friedrich Silcher, Friedrich Erk. - Lahr, 1896-1906.URL:http://de. wikipedia.org/wiki/ Allgemeines_Deutsches_Kommersbuch

17. Seneca. De brevitate vitae. URL:http://www.latin.it/autore/seneca/de_br evitate_vitae

\section{References}

1. Mironova, V. M., Mikhailova O. G., Megela I. P. (2005), Antychna literatura [Ancient literature]. Kyiv: Libid, 488.

2. Vakulyk, I. I. (2011), Dzherela pokhodzhennia kultu starovynnoi studentskoi pisni [Sources of the origin of the cult of ancient student songs]. Studia Linguistica, 2011. Вип. 5. Ч. 2. С. 64-70.

3. Golubeva, M. (2008), St. Petersburg University, №11 (3778), August 29.
4. Dvoretskyi, I. Kh. (1996), Latynskorusskyi slovar [Latin-Russian dictionary] Moscow: Russian, 1096.

5. Koval, A. P. (2001), Spochatku bulo Slovo: Krylati vyslovy biblinoho pokhodzhennia $v$ ukrainskii movi [The first was the Word]: Winged Sayings of Biblical Origin in Ukrainian. Kyiv: Libid, 312.

6. Sodomora, A. (2000), Ne dostizheniya tekhniki, a ves Slova $v$ obshhestve opredelyaet meru ego tsivilizovannosti [Not attainment of technology, but the weight of the Word in society determines the measure of its civilization] Den' [Day], № 226, December 8.

7. Fedorov, N. (2001), «Vozveselimsya zhe!» [«Let's Have Fun!»] Nezavisimaya gazeta [Nezavisimaya Gazeta], № 12 (2322), January 25.

8. Florensky, P. Khristianstvo i kul'tur. Simvol [Christianity and Culture]. Simvol [Symbol], XXI, 69-83.

9. Brockhaus, F. A, Efron, I. A. (18901907), Entsiklopedicheskij slovar' Encyclopedic Dictionary St. Petersburg: Typographer. acc. total Brockhaus-Efron. http:// http://www.vehi.net/brokgauz/

10. Allgemeines Deutsches Commersbuch. $\quad 1858$. http://www.academiccorporations.org/world/ita ly/history.

11.Ames, J. S. Biographical Memoir. Vol. XXIII. National Academy of Sciences of the United States of America. Presented to the Academy at the annual meeting, 1944. p.186.http://www.nap.edu/html/biomems/jame s.pdf.

12. Gaudeamus igitur. Lat uns frhlich sein. Historische Studentenlieder, zusammengestellt, bearbeitet und kommentiert von Gnter Steiger und Hans-Joachim Ludwig, 1. Auflage Leipzig (DDR) 1986, 3. Auflage, Leipzig (DDR) 1989. http://www.akadpress.de/studentika/bueche r/steigergaudeamusigitur.htm

13. Gaudeamus igitur, el himno universitario / 500 aos en la historia de Sevilla.URL:http://personal.us.es/alporu/hist oria/gaudeamus.html

14. Kindleben, C., Augustin, C. Deutscher Abend in Halle, Verlag Fliegenkopf, Halle, Reprint der Ausgabe 
von $1894, \quad 2000 . \quad$ URL: http://www.arbeitsgemeinschaft.net/article/ Gaudeamus_igitur

15. Probst-Effah G. "Gaudeamus igitur» - ein Beitrag zum deutschen Studentenlied. Gisela Probst-Effah. http://deutsch.astrasong.ru/c/de/art/466

16. Schauenburg,

M. Allgemeines
Deutsches Kommersbuch / Herausgeber: Friedrich Silcher, Friedrich Erk. - Lahr, 1896-1906.

URL:http://de.wikipedia.org/wiki/Allgemeine s_Deutsches_Kommersbuch

17. Seneca. De brevitate vitae. URL:http://www.latin.it/autore/seneca/de_br evitate_vitae

\title{
ГАУДЕАМУС: ВІД ДЖЕРЕЛ ПОХОДЖЕННЯ ДО КУЛЬТУ
}

\section{І. І. Вакулик}

\begin{abstract}
Анотація. У статті розглядаються існуючі варіанти стародавньої студентської пісні та визначається першоджерело всесвітньо відомого гімну. Мета представленої роботи - виокремити і дослідити інтерпретації стародавньої студентської пісні, встановити їх підпорядкованість та авторство, визначити першоджерело всесвітньо відомого гімну. Наукова новизна полягає у виявленні механізму створення середньовічної пісні "Gaudeamus» та сучасному ї̈ прочитанні. Дослідження проводилось на основі аналізу латинського тексту всесвітньовідомої поезії у контексті сучасного їі трактування науковцями України, Німеччини, Іспанії, Росії. У роботі виявлено максимальну об'єктивність щодо викладу фрактографрічного матеріалу. 3 метою вивчення досліджуваного твору використано метод діалогічної інтерпретації тексту, зокрема його культурно-історичний аспект.
\end{abstract}

Ключові слова: сучасний гімн студентства, середньовічні пісні вагантів, «Gaudeamus», френомен сприйняття, інтерпретація. 